\title{
Modeling the distribution of rock mass and native copper output by size classes during crushing
}

\author{
Valerii Korniyenko, ${ }^{1,}$, Yevhenii Malanchuk ${ }^{1}$, Andriy Khrystyuk $^{1}$, Valentyna Kostrychenko ${ }^{1}$, Assel Shampikova ${ }^{2}$, Kulzhamal \\ Nogaeva ${ }^{3}$, and Almaz Kozhonov ${ }^{3}$ \\ ${ }^{1}$ National University of Water and Environmental Engineering, 11 Soborna Str., Rivne, 33028, Ukraine \\ ${ }^{2}$ Satbayev University, 22 Satpaev Str., Almaty, 050013, Kazakhstan \\ ${ }^{3}$ Kyrgyz State University of Geology, Mining, and Natural Resources Development named after Academician U. Asanaliev, 215 Chui \\ Ave., Bishkek, Kyrgyz Republic
}

\begin{abstract}
The article considers the features of the distribution of technological indicators (product output, content and extraction of copper) by size classes, the main factors influencing the crushing process are identified and regression dependences of productivity on influencing factors are received. The parabolic nature of the dependences of the output of crushed rock on the size class is established. The high adequacy of the obtained models was confirmed and the most promising classes of rock size for copper extraction were determined. The obtained results and models will allow to develop a generalized model of the process of native copper mining and to implement this process with rational and optimal parameters. Also, the received models will allow to carry out an estimation of productivity of a research site of processing of raw materials of basalt quarries.
\end{abstract}

\section{Introduction}

Historical and archeological data indicate that Volyn native copper was well known to the ancient Slavs. This is evidenced by the names of places (Midsk, Medishche, etc.) of Old Slavic origin (mid - copper), tools from ancient settlements and ancient basalt mines in the basin of the Goryn River. The first thorough written data on Volyn native copper appeared in the Polish geological literature in the late $1920 \mathrm{~s}$, although some publications as early as 1887 already mention Volyn native copper.

In addition to Volyn copper, several other rich manifestations of native copper have been discovered in Ukraine relatively recently. All these previously unknown ore occurrences were found on the Ukrainian Shield. In the early 1990s, native copper was found among polymetallic ores in the Precambrian carbonate rocks of the Volyn mega block (Kurchytsia ore occurrence), and at the beginning of the new millennium in the weathering crust of the Zhdaniv ultrabasic intrusion in the 2003 Berdychiv uplift and uplift. Chemerpil structure of the Podolsk block. Rare finds of native copper are known in the Carpathians, Azov, Donbass and Kryvyi Rih.

Xenomorphic native copper predominates in the ore manifestations of Ukraine due to a significant influence on the shape of its allocations in the crystallization medium. There is a significant variety of xenomorphic forms of native copper - lamellar, membranous, druse-, vein-, dendritic-, lump-, droplet-, wire-, sponge-, needleand hair-like. Among the small allocations of copper are often perfect and imperfect polyhedra, their regular and irregular growths, dendrites and dendritoids.

The dominant method of growth of polyhedra of native copper of Ukraine is free crystallization, the tangential mechanism of growth of crystals prevailed. Crystals of hydrothermal copper from volcanic of Volyn grew in cubic layers, as well as crystals of hyper genic copper from the Zhdanovka ore occurrence, while crystals of hypergenic copper from the Chemerpil ore occurrence grew in octahedral layers.

In terms of chemical composition, copper from ore occurrences in Ukraine is a relatively pure mineral, especially in the case of hydrothermal native copper from volcanic of the Volyn copper ore district. Magmatic copper from volcanic of Volyn has a high content of impurities $\mathrm{Ni}, \mathrm{Co}, \mathrm{Cr}$ and $\mathrm{Fe}$ [1].

Important minerals-indicators of native copper mineralization in the volcanic of Volyn are native iron and silver, which have characteristic features of chemical composition: iron enriched with impurities $\mathrm{Mn}$ and $\mathrm{Cr}$, silver - Hg. In terms of crystal morphological features, hydrothermal native copper from Volyn volcanic is most similar to native copper from Michigan deposits (USA), which indicates the close conditions of their crystallization [2].

Native copper of Ukraine belongs to several genetic types: a) hypo genic (magmatic and post-magmatic hydro-thermal) in the Vendian volcanic of the Volyn copper ore district; b) hyper genic in the oxidation zones of the Precambrian ultrabasites of the Zhdanovka and Chemerpil ore occurrences of the Podil block of the

\footnotetext{
* Corresponding author: kvja@i.ua
} 
Ukrainian Shield; c) metamorphogenic in Precambrian metamorphic rocks ore occurrence of Kurchytsia of the Volyn megablock of the Ukrainian Shield [3-7].

\section{Methods}

As you know, the average copper content in the main geological and industrial types of copper deposits is from 0.2 to $6.0 \%$ (for example, for cuprous sandstones and shale $1.0-6.0 \%$, for deposits of native copper $1.0-2.5 \%$ ) [8]. The lower limit of the conditions for copper ore is the copper content in the ore $0.35-0.50 \%$, for oxidized ores, according to world practice, this limit is higher - from 0.7$1.0 \%$ at which its industrial use is technically possible and economically expediently [9].

Sulfide copper ores make up $90 \%$ of all industrially processed copper ores. They are finely crushed and enriched by flotation, for oxidized ores the most common and cheapest method is hydrometallurgy (leaching and extraction of copper from solution), ore preparation of oxidized and native ores, as a rule, includes gravity methods [10].

Studies of rocks from basalt quarries in Volyn (Rafalovsky, Berestovetsky and some others) did not reveal the presence of sulfide copper ores in an amount sufficient for industrial processing, mainly copper is contained in the form of native mineralization and accompanying oxidized varieties [11]. Considering this, when extracting copper from basalt quarry rocks, the main thing is to create a strong, developed ore preparation scheme. Further, copper can be obtained from the concentrate of ore preparation, either by modifying it by hydrometallurgy or roasting-flotation concentration, or directly by smelting (pyro metallurgy).

Due to the fact that all three main rocks of the open pit are copper-bearing - tuff, basalt, lavobrekcia, it is necessary to clarify in advance, at least in general terms, whether the ore preparation scheme will be the same for all three rocks or will it be necessary to create separate processing lines. For this, the prepared representative rock samples were uniformly detailed (on a roller crusher) and dispersed into three narrow particle size classes.

To determine the nature of the distribution of native copper in different grades of the size of the crushed rock, studies of technological samples of lumpy lava breccia with pronounced numerous inclusions of copper were carried out [12]. Sampling was carried out on the blasted rock mass at different points along the face of the Rafalovsky basalt quarry. A total of 10 samples were taken, each weighing $10 \mathrm{~kg}$ in the form of a single piece or a set of separate pieces.

Crushing was carried out on a vibration-type jaw crusher with an adjustable slit for unloading the crushed mass. After crushing each sample, the resulting mass was vibrated and divided into six control size classes. The weight of the sample as a whole, the weight of each screening class and the weight content of copper in each of the classes and in the sample as a whole were measured [13-16].

\section{Results and discussion}

Experimental studies have shown that in all classes the copper content is not more than $4.1 \%$, that is, not excluding the presence of nuggets and pure grains of copper minerals in the classes, there is a lot of waste rock in all classes and, most importantly, there are many intergrowths of copper minerals with the rock. To destroy the aggregates, these classes will have to be crushed, otherwise the aggregates will be extracted during enrichment and the quality of the concentrate will be insufficient [17].

Based on the experiments carried out, for 10 samples of lavobrekcia, the cumulative (cumulative) characteristics of copper extraction into classes were constructed (Table 1).

Table 1. Cumulative characteristics of copper recovery in size classes of crushed mass of lavobrekcia.

\begin{tabular}{|c|c|c|c|c|c|c|c|c|c|c|c|}
\hline $\begin{array}{c}\text { Classes, } \\
\mathbf{m m} /\end{array}$ & \multicolumn{7}{|c|}{ Total copper recovery, } & \multirow{2}{*}{ Average } \\
\cline { 2 - 4 } & $\mathbf{1}$ & $\mathbf{2}$ & $\mathbf{3}$ & $\mathbf{4}$ & $\mathbf{5}$ & $\mathbf{6}$ & $\mathbf{7}$ & $\mathbf{8}$ & $\mathbf{9}$ & $\mathbf{1 0}$ & \\
\hline+10 & 21.4 & 14.7 & 17.2 & 15.7 & 20.0 & 26.0 & 29.0 & 24.3 & 22.0 & 22.2 & 21.3 \\
\hline$-10+5$ & 44.7 & 42.3 & 46.8 & 36.2 & 35.6 & 58.5 & 60.3 & 53.5 & 50.9 & 48.3 & 47.7 \\
\hline$-5+1.0$ & 70.7 & 64.6 & 71.9 & 64.4 & 55.6 & 70.0 & 85.8 & 73.5 & 74.1 & 72.4 & 70.3 \\
\hline$-1.0+0.5$ & 85.4 & 78.8 & 84.9 & 81.1 & 76.8 & 86.2 & 92.2 & 88.0 & 90.5 & 84.8 & 84.9 \\
\hline$-0.5+0.1$ & 94.1 & 89.8 & 93.3 & 90.4 & 89.0 & 100 & 96.5 & 95.5 & 97.6 & 93.5 & 94.0 \\
\hline$-0.1+0.05$ & 100.0 & 100.0 & 100.0 & 100.0 & 100.0 & - & 100.0 & 100.0 & 100.0 & 100.0 & 100.0 \\
\hline
\end{tabular}

Table 1 shows that, on average, the total extraction of copper in the top three classes $-10+1 \mathrm{~mm}$ is $70.3 \%$, in classes $-10+0.5$ about $85 \%$, and in classes $-10+0.1 \mathrm{~mm}$ - $94 \%$. This concentration of copper in relatively large grades is typical for native deposits.

Using the obtained data on extraction, two conclusions can be drawn, firstly, regarding the structural diagram of the developed ore preparation technology, and secondly, about the expected performance of copper concentrate.

The nature of the extraction (Table 1) suggests the possibility of using a variant of the technology for separate enrichment of lavobrekcia, when the raw material is divided into two streams - large and small classes, each of which is enriched separately. The decision on which size to accept as the boundary will depend on the chosen method of enrichment, since the enrichment equipment operates at a certain lower limit of the feed size. For example, grades $+0.5 \mathrm{~mm}$, where copper recovery is $85 \%$, are easily enriched by gravity methods, for example, jigging [18-23]. Classes $+0.1 \mathrm{~mm}$, the recovery in which is higher than $94 \%$, are well enriched on concentration tables and corona electrostatic separators [24].

The second possible variant of the technology is simpler - it is possible, without dividing the raw material into two streams, in the head of the diagram from large classes to isolate native formations by gravity methods. This approach is often used for gold-bearing ores - native mineralization is extracted by gravity, or, as they say in the practice of beneficiation, the valuable component is 
removed, that is, a rich gravity concentrate is obtained, and the remaining product is enriched in the usual way.

Extraction, as a technological indicator, characterizes not so much the raw material as the method or equipment for enrichment. In the practice of beneficiation, the concept of extraction is rarely used, since it is a complex indicator that does not provide information either on the yield of the concentrate or on its quality - the copper content in it. In practice, they strive to achieve a maximum of both yield and quality, and they do not operate on extraction. However, extraction, as a complex indicator, is indispensable for making forecasts and estimates.

So, using the recovery rate, it is possible to predict the possibility of obtaining standard copper concentrate with a content of $15 \%$ from lavobrekcia $\mathrm{Cu}$ (according to GOST 52998-2008, copper concentrate must contain at least $15 \%$ copper (sometimes $12 \%$ )). To determine the yield (amount) of concentrate, let us set the copper content in the feedstock and the extraction.

As the copper content in the original product $(\alpha)$, we take from table 2 the highest copper content in the samples is $1.5 \%$. Let's set the final recovery of $85 \%$. Let us make a preliminary remark regarding this extraction figure.

According to the practice of enrichment of copper ores, recovery of $85 \%$ is a very high indicator. Thus, the most efficient flotation method today provides recovery of $70-80 \%$. For example, $\varepsilon=70 \%$ for the main copper flotation at the Krasnouralsk plant, $\varepsilon=75 \%$ for the collective flotation of the Udokan mixed oxidized and sulfide copper ores. In about $10 \%$ of cases, flotation yields $82 \%$ recovery and very rarely $85 \%$. The same applies to the gravitational enrichment of non-ferrous metals, where the typical recovery is $60-70 \%$, not higher than $80 \%$ [2528].

Thus, in the best case, with $\alpha=1.7 \%, \varepsilon=85 \%$, the yield of concentrate from lavobrekcia will be $\gamma=\frac{\alpha \cdot \varepsilon}{\beta}=\frac{1.7 \cdot 85}{15}=9.6 \%$.

It follows that the original sample must be reduced by at least 10 times to obtain a concentrate with a quality of $15 \%$. If the recovery is less, then the yield of the concentrate will be less.

For example, for the same high-grade ore, with $\varepsilon=70 \%, \gamma=\frac{\alpha \cdot \varepsilon}{\beta}=\frac{1.7 \cdot 70}{15}=7.9 \%$.

Also, the poorer the feedstock, the lower the concentrate yield will be, since the more waste rock must be discarded to obtain a concentrate of a given quality. For example, with a copper content of $0.5 \%$ in the original and a high $\varepsilon=85 \%$, the yield of a concentrate with a quality of $15 \%$ will be only $\gamma=2.8 \%$.

The average technological characteristics of raw materials were calculated - for all 10 samples of crushed lava breccia (Table 2).

Table 2 shows that all size classes contain a lot of copper (more than $0.35 \%$ - the industrially necessary minimum), that is, none of the classes can be removed from the redistribution of copper concentration.

Also, the data in Table 2 show the highest absolute copper recovery of $21-26 \%$ for the three upper classes -
$10+1 \mathrm{~mm}$. The same classes have the highest copper content of $1.1-1.5 \%$. According to the norms, it is required to obtain a standard concentrate with a copper content of at least 10-12 times more (the quality of standard copper concentrates is from 15 to $28 \% \mathrm{Cu}$ ). In principle, it is possible to divide raw materials according to the $1 \mathrm{~mm}$ class, and everything that is finer can be subjected, for example, to direct enrichment by hydrometallurgy (leaching), but everything that is larger will first have to be crushed and only then enriched. When grinding large grades, copper will not disappear, it will go into smaller grades, which can already be effectively enriched.

Table 2. Average values for 10 samples of lavobrekcia.

\begin{tabular}{|c|c|c|c|c|c|}
\hline \multirow{2}{*}{$\begin{array}{c}\text { Classes, } \\
\mathbf{m m}\end{array}$} & \multirow{2}{*}{$\begin{array}{c}\text { Output, } \\
\gamma, \%\end{array}$} & \multirow{2}{*}{$\begin{array}{c}\text { Copper } \\
\text { content, } \\
\beta, \%\end{array}$} & \multirow{2}{*}{$\begin{array}{c}\text { Extraction of } \\
\text { copper, } \\
\varepsilon, \%\end{array}$} & \multicolumn{2}{|c|}{ Total extraction } \\
\hline & & & & $\begin{array}{c}\text { Output, } \\
\%\end{array}$ & $\mathrm{Cu}, \%$ \\
\hline+10 & 18.0 & 1.3 & 21.3 & 18.0 & 21.3 \\
\hline$-10+5$ & 19.0 & 1.5 & 26.5 & 37.0 & 47.7 \\
\hline$-5+1.0$ & 21.5 & 1.1 & 22.6 & 58.5 & 70.3 \\
\hline$-1.0+0.5$ & 16.0 & 1.0 & 14.6 & 74.5 & 84.9 \\
\hline$-0.5+0.1$ & 14.0 & 0.7 & 9.1 & 88.5 & 94.0 \\
\hline $\begin{array}{c}- \\
0.1+0.05 \\
\end{array}$ & 11.5 & 0.6 & 6.0 & 100.0 & 100.0 \\
\hline Total & 100.0 & 1.06 & 100.0 & & \\
\hline
\end{tabular}

Let us carry out an estimated calculation of the amount (yield) of standard copper concentrate from lavobrekcia. As you can see from the table. 2, the average copper content for 10 tests was $1.06 \%$. To obtain a standard concentrate with a lower quality limit of $15 \%$ at a recovery of, for example, $70 \%$, the initial quantity of raw materials must be reduced to $\gamma=\frac{\alpha \cdot \varepsilon}{\beta}=\frac{1.06 \cdot 70}{15}=5.0 \%$

Even with $\varepsilon=90 \%$ (not achievable in practice), the yield of the standard concentrate will be small, only $6.4 \%$. The estimated yield values obtained show that during ore preparation it is necessary to strive to reduce the mass of raw materials as much as possible, but without losing the valuable component. So, with a copper content of 0.5 $1.7 \%$ in lavobrekcia, to obtain a concentrate with a quality of $15 \%$, the mass of raw materials must be reduced to 5$10 \%$ of the original amount [29].

Thus, 10 representative samples of lavobrekcia from the Rafalovsky basalt quarry with a copper content of 0.5 to $1.7 \%$ were experimentally studied, which were separately subjected to crushing on a vibration-type jaw crusher with an adjustable discharge slot and vibrating screening with division into six control size classes. As a result, the main technological indicators were established - the yield, content and extraction of copper in narrow grain size classes of crushing products and the dependences of the distribution of these indicators by size classes were obtained [30].

The cumulative sieve characteristics showed that the crushing size was $20 \%$ cell $-0.1 \mathrm{~mm}$, on average $11.5 \%$ cell $-0.1 \mathrm{~mm}$.

The dependences of the distribution of copper by size classes showed that the content of copper in small classes $-1 \mathrm{~mm}$ is less than in large ones $+1 \mathrm{~mm}$ ( 8 samples out of 
10). In large grades of $-10+1 \mathrm{~mm}$, the distribution of copper content is almost uniform. In general, the distribution of copper by size class, with sufficient accuracy for practice, is described by a logarithmic relationship, which is pronounced for rich samples ( $\beta \geq 1 \%$ ) (6 samples). For poorer samples $(\beta \approx 0.5 \%)$, the logarithmic dependence flattens out and, with an accuracy sufficient for practice, can be considered linear (4 samples). More precise mathematical approximations of the distribution of the mass of raw materials and the amount of copper by size will be considered below. All grades of lavobrekcia size, including the thinnest -0.1 $+0.05 \mathrm{~mm}$, have a standard copper content and cannot be removed from the copper concentration redistribution.

The dependences of copper recovery on the particle size showed that with an increase in the size, the recovery monotonically increases up to a certain limit and, starting with a particle size of about 1-2 $\mathrm{mm}$, the nature of the dependences flattens out. The total extraction of copper in the upper size classes $-10+1 \mathrm{~mm}$ is $70.3 \%$, in the wider class $-10+0.1 \mathrm{~mm}-94 \%$.

When the copper content in the lavobrekcia samples is $0.5-1.7 \%$ to obtain a concentrate with a lower quality limit of $15 \%$ (GOST 52998-2008), the mass of the rock must be reduced to $5-10 \%$ of the initial amount of raw materials. Two variants of the technological scheme can be considered as promising - with the separation of a rich gravity concentrate in the head of the process and with separate enrichment of large and small classes according to the main and sludge scheme.

For the development of ore preparation technology, it is important to determine the calculation formulas that provide, in particular, the forecast of the copper yield depending on the crushing size. Previous studies have established experimental dependences of the yield, grade and recovery of copper on the size for 10 samples of crushed lavobrekcia. In this case, the grain size distribution of each initial sample was arbitrary and the samples were subjected to crushing. Since after crushing the output of the rock mass into each of the 6 classes of sieving (vibrating screening was used) was different for each of the 10 samples, then to obtain a generalized characteristic, it is necessary to establish the regularities of the distribution of the rock mass output and the output of native copper from the size. The initial experimental data for determining these patterns are given in Tables 37.

For such studies, first of all, the assumption about the subordination of the yield of the breed to the class to the normal distribution law is checked. To check compliance with the theoretical distribution law, the criteria of agreement of Pearson, Kolmogorov, Shapiro-Wilk, and others are applicable. However, most of these criteria are suitable only for medium to large samples. In our case, the sample is small $(n=10)$, these criteria are not applicable.

The studies carried out were based on the well-known method of analysis of small samples [31], according to which selective without bias and kurtosis can be used for an approximate test of the hypothesis of the normal distribution.
Table 3. Initial experimental data for determining the amount of copper in the class.

\begin{tabular}{|c|c|c|c|c|c|c|}
\hline \multirow{3}{*}{$\begin{array}{c}\text { Size } \\
\text { classes, } \\
\text { mm }\end{array}$} & \multicolumn{3}{|c|}{ Try №1 } & \multicolumn{3}{|c|}{ Try №2 } \\
\hline & \multirow[t]{2}{*}{$\begin{array}{l}\text { Hitch } \\
\text { weight } \\
\text { in the } \\
\text { class, } \\
\mathbf{x}, \mathrm{kg}\end{array}$} & \multicolumn{2}{|c|}{$\begin{array}{c}\text { Copper } \\
\text { weight in } \\
\text { class, } \\
X_{m}\end{array}$} & \multirow[t]{2}{*}{$\begin{array}{l}\text { Hitch } \\
\text { weight } \\
\text { in the } \\
\text { class, } \\
\mathrm{x}, \mathrm{kg}\end{array}$} & \multicolumn{2}{|c|}{$\begin{array}{c}\text { Copper } \\
\text { weight in } \\
\text { class, } \\
X_{m}\end{array}$} \\
\hline & & $\mathbf{g}$ & $\%$ & & $\mathbf{g}$ & $\%$ \\
\hline+10 & 1.5 & 33.5 & 19.7 & 1.5 & 20.1 & 14.7 \\
\hline$-10+5$ & 1.0 & 40.5 & 23.8 & 1.5 & 37.9 & 27.7 \\
\hline$-5+1.0$ & 2.5 & 45.1 & 26.5 & 1.5 & 30.5 & 22.3 \\
\hline$-1.0+0.5$ & 1.0 & 25.6 & 15.1 & 2.0 & 19.5 & 14.2 \\
\hline$-0.5+0.1$ & 2.5 & 15.1 & 8.9 & 1.5 & 15.0 & 10.9 \\
\hline$-0.1+0.05$ & 1.5 & 10.2 & 6.0 & 2.0 & 14.0 & 10.2 \\
\hline Total & 10.0 & 170.0 & 100.0 & 10.0 & 137.0 & 100.0 \\
\hline
\end{tabular}

Table 4. Initial experimental data for determining the amount of copper in the class.

\begin{tabular}{|c|c|c|c|c|c|c|}
\hline \multirow{3}{*}{$\begin{array}{c}\text { Size } \\
\text { classes, } \\
\text { mm }\end{array}$} & \multicolumn{3}{|c|}{ Try №3 } & \multicolumn{3}{|c|}{ Try №4 } \\
\hline & \multirow[t]{2}{*}{$\begin{array}{l}\text { Hitch } \\
\text { weight } \\
\text { in the } \\
\text { class, } \\
x, k g\end{array}$} & \multicolumn{2}{|c|}{$\begin{array}{c}\text { Copper } \\
\text { weight in } \\
\text { class, } \\
X_{m}\end{array}$} & \multirow{2}{*}{$\begin{array}{l}\text { Hitch } \\
\text { weight } \\
\text { in the } \\
\text { class, } \\
x, k g\end{array}$} & \multicolumn{2}{|c|}{$\begin{array}{c}\text { Copper } \\
\text { weight in } \\
\text { class, } \\
X_{m}\end{array}$} \\
\hline & & g & $\%$ & & g & $\%$ \\
\hline+10 & 2.0 & 16.5 & 17.2 & 1.5 & 12.4 & 15.7 \\
\hline$-10+5$ & $2 . .0$ & 28.4 & 29.6 & 2.0 & 16.2 & 20.5 \\
\hline$-5+1.0$ & 1.5 & 24.1 & 25.1 & 2.5 & 22.3 & 28.2 \\
\hline$-1.0+0.5$ & 1.0 & 12.4 & 12.9 & 2.0 & 13.2 & 16.7 \\
\hline$-0.5+0.1$ & 1.5 & 8.1 & 8.4 & 1.0 & 7.3 & 9.2 \\
\hline$-0.1+0.05$ & 2.0 & 6.4 & 6.7 & 1.0 & 7.6 & 9.6 \\
\hline Total & 10.0 & 95.9 & 100.0 & 10.0 & 79.0 & 100.0 \\
\hline
\end{tabular}

Table 5. Initial experimental data for determining the amount of copper in the class.

\begin{tabular}{|c|c|c|c|c|c|c|}
\hline \multirow{3}{*}{$\begin{array}{c}\text { Size } \\
\text { classes, } \\
\text { mm }\end{array}$} & \multicolumn{3}{|c|}{ Try №5 } & \multicolumn{3}{|c|}{ Try №6 } \\
\hline & \multirow[t]{2}{*}{$\begin{array}{l}\text { Hitch } \\
\text { weight } \\
\text { in the } \\
\text { class, } \\
x, k g\end{array}$} & \multicolumn{2}{|c|}{$\begin{array}{c}\text { Copper } \\
\text { weight in } \\
\text { class, } \\
X_{m} \\
\end{array}$} & \multirow{2}{*}{$\begin{array}{l}\text { Hitch } \\
\text { weight } \\
\text { in the } \\
\text { class, } \\
\mathrm{x}, \mathrm{kg}\end{array}$} & \multicolumn{2}{|c|}{$\begin{array}{c}\text { Copper } \\
\text { weight in } \\
\text { class, } \\
X_{m} \\
\end{array}$} \\
\hline & & $\mathbf{g}$ & $\%$ & & $\mathbf{g}$ & $\%$ \\
\hline+10 & 2.0 & 10.5 & 20.0 & 2.0 & 12.2 & 26.0 \\
\hline$-10+5$ & 1.0 & 8.2 & 15.6 & 3.0 & 15.3 & 32.6 \\
\hline$-5+1.0$ & 2.0 & 10.5 & 20.0 & 2.0 & 5.4 & 11.5 \\
\hline$-1.0+0.5$ & 3.0 & 11.1 & 21.1 & 3.0 & 7.6 & 16.2 \\
\hline$-0.5+0.1$ & 1.5 & 6.4 & 12.2 & - & 6.5 & 13.8 \\
\hline$-0.1+0.05$ & 1.5 & 5.8 & 11.0 & - & - & \\
\hline Total & 11.0 & 52.5 & 100.0 & 10.0 & 47.0 & 100.0 \\
\hline
\end{tabular}

Table 6. Initial experimental data for determining the amount of copper in the class.

\begin{tabular}{|c|c|c|c|c|c|c|}
\hline \multirow{3}{*}{$\begin{array}{c}\text { Size } \\
\text { classes, } \\
\text { mm }\end{array}$} & \multicolumn{3}{|c|}{ Try №7 } & \multicolumn{3}{|c|}{ Try №8 } \\
\hline & \multirow[t]{2}{*}{$\begin{array}{l}\text { Hitch } \\
\text { weight } \\
\text { in the } \\
\text { class, } \\
x, k g\end{array}$} & \multicolumn{2}{|c|}{$\begin{array}{c}\text { Copper } \\
\text { weight in } \\
\text { class, } \\
X_{m}\end{array}$} & \multirow{2}{*}{$\begin{array}{l}\text { Hitch } \\
\text { weight } \\
\text { in the } \\
\text { class, } \\
x, \text { kg }\end{array}$} & \multicolumn{2}{|c|}{$\begin{array}{c}\text { Copper } \\
\text { weight in } \\
\text { class, } \\
X_{m}\end{array}$} \\
\hline & & $\mathbf{g}$ & $\%$ & & $\mathrm{~g}$ & $\%$ \\
\hline+10 & 2.0 & 41.8 & 29.0 & 2.0 & 27.1 & 24.3 \\
\hline$-10+5$ & 2.0 & 45.1 & 31.3 & 2.0 & 32.4 & 29.1 \\
\hline$-5+1.0$ & 2.0 & 36.7 & 25.5 & 2.5 & 22.3 & 20.0 \\
\hline$-1.0+0.5$ & 1.0 & 9.1 & 6.3 & 1.5 & 16.1 & 14.5 \\
\hline$-0.5+0.1$ & 1.5 & 6.2 & 4.3 & 1.0 & 8.4 & 7.5 \\
\hline$-0.1+0.05$ & 1.5 & 5.1 & 3.5 & 1.0 & 5.0 & 4.5 \\
\hline Total & 10.0 & 144.0 & 100.0 & 10.0 & 111.3 & 100.0 \\
\hline
\end{tabular}


Table 7. Initial experimental data for determining the amount of copper in the class.

\begin{tabular}{|c|c|c|c|c|c|c|}
\hline \multirow{3}{*}{$\begin{array}{l}\text { Size } \\
\text { classes, } \\
\text { mm }\end{array}$} & \multicolumn{3}{|c|}{ Try №9 } & \multicolumn{3}{|c|}{ Try №10 } \\
\hline & \multirow[t]{2}{*}{$\begin{array}{l}\text { Hitch } \\
\text { weight } \\
\text { in the } \\
\text { class, } \\
x, k g\end{array}$} & \multicolumn{2}{|c|}{$\begin{array}{c}\text { Copper } \\
\text { weight in } \\
\text { class, } \\
X_{m}\end{array}$} & \multirow{2}{*}{$\begin{array}{l}\text { Hitch } \\
\text { weight } \\
\text { in the } \\
\text { class, } \\
\mathbf{x}, \mathbf{k g}\end{array}$} & \multicolumn{2}{|c|}{$\begin{array}{c}\text { Copper } \\
\text { weight in } \\
\text { class, } \\
X_{m}\end{array}$} \\
\hline & & g & $\%$ & & g & $\%$ \\
\hline+10 & 1.0 & 38.1 & 22.0 & 2.5 & 10.2 & 22.2 \\
\hline$-10+5$ & 1.5 & 50.0 & 28.9 & 3.0 & 12.0 & 26.1 \\
\hline$-5+1.0$ & 2.0 & 40.1 & 23.2 & 3.0 & 11.1 & 24.1 \\
\hline$-1.0+0.5$ & 3.0 & 28.4 & 16.4 & 0.5 & 5.7 & 12.4 \\
\hline$-0.5+0.1$ & 2.5 & 12.3 & 7.1 & 0.5 & 4.0 & 8.7 \\
\hline$-0.1+0.05$ & 0.5 & 4.1 & 2.4 & 0.5 & 3.0 & 6.5 \\
\hline Total & 10.5 & 173.0 & 100.0 & 10.0 & 46.0 & 100,0 \\
\hline
\end{tabular}

Sample values of without bias and kurtosis are compared with the standard deviations of asymmetry and kurtosis, and the results of the comparison are used to judge the agreement with the normal distribution law [3236].

The yield of classes is not given (\%), but the yield of copper per class of the total amount of copper in the sample (\%). The yield of the size class and the yield of copper in the class are different indicators. The calculation of the extraction for the specified yield of copper in the class is incorrect (the balance is not observed).

The calculation procedure in this case is as follows.

A sample is given (testing results):

$$
x_{1}, x_{2} \ldots, x_{n},
$$

where $n$-sample size.

We calculate the following indicators:

- average value:

$$
\dddot{x}=\frac{\sum x_{i}}{n}
$$

- variance:

$$
S^{2}=\frac{\sum x_{i}^{2}}{n}-\dddot{x}^{2}
$$

- standard deviation:

$$
S=\sqrt{S^{2}}
$$

- asymmetry:

$$
A_{S}=\frac{\sum\left(x_{i}-\dddot{x}\right)^{3}}{n \cdot S^{3}}
$$

- excess:

$$
E=\frac{\Sigma\left(x_{i}-\dddot{x}\right)^{4}}{n \cdot S^{4}}-3
$$

- standard deviation for asymmetry:

$$
S_{A S}=\sqrt{\frac{6 \cdot(n-1)}{(n+1)(n+3)}} ;
$$

- standard deviation for kurtosis:

$$
S_{A S}=\sqrt{\frac{24 \cdot(n-2)(n-3) n}{(n-1)^{2}(n+3)(n+5)}} .
$$

If the absolute values of without bias and kurtosis do not exceed their standard deviations, then the hypothesis about the agreement of the sample with the normal distribution law is confirmed.

Calculation results for the rate of rock mass (rock) yield into classes $\gamma_{n i}, 1,2, \ldots, 6$ (Table 8).

Table 8. Dependence of rock yield on controlled size classes.

\begin{tabular}{|c|c|c|c|c|c|c|}
\hline Class & $\begin{array}{c}\text { Size } \\
\text { limits in } \\
\text { class, } \\
\mathbf{m m}\end{array}$ & $\begin{array}{c}\text { Average } \\
\text { breed } \\
\text { yield in } \\
\text { the class, } \\
\boldsymbol{X}_{\boldsymbol{m}, \mathbf{k g}}\end{array}$ & $\begin{array}{c}\text { Average } \\
\text { sample } \\
\text { weight in } \\
\text { a class of } \\
\mathbf{1 0} \\
\text { samples, } \\
\boldsymbol{X}_{\boldsymbol{m}, \mathbf{~ k g}}\end{array}$ & $\begin{array}{c}\text { Standard } \\
\text { deviation, } \\
S\end{array}$ & $\begin{array}{c}\text { Asym- } \\
\text { metry, } \\
A_{S}\end{array}$ & $\begin{array}{c}\text { Excess, } \\
\boldsymbol{E}\end{array}$ \\
\hline 1 & $0.1-0.05$ & 0.115 & 1.15 & 0.634 & -0.280 & -1.200 \\
\hline 2 & $0.5-0.1$ & 0.135 & 1.35 & 0.743 & -0.025 & -0.584 \\
\hline 3 & $1.0-0.5$ & 0.175 & 1.75 & 0.844 & 0.187 & -1.300 \\
\hline 4 & $5.0-1.0$ & 0.205 & 2.05 & 0.567 & -0.196 & -0.753 \\
\hline 5 & $5.0-10.0$ & 0.190 & 1.90 & 0.663 & 0.370 & -0.780 \\
\hline 6 & +10 & 0.180 & 1.80 & 0.400 & -0.328 & -0.336 \\
\hline
\end{tabular}

We have for the sample size $n=10$ :

$$
S_{A S}=0.615 ; S_{E}=0.922 \text {. }
$$

Comparing without bias and kurtosis with these critical values, we note that in the overwhelming majority of cases, the condition of agreement of the sample with the specified distribution law is satisfied. Only in two cases does excess exceed the critical value (for classes $1 \ldots$ $0.5 \mathrm{~mm}$ and $0.1 \ldots 0.05 \mathrm{~mm}$ ), but this excess can be considered insignificant [37].

Thus, it can be argued that the rock yield is consistent with the normal distribution law.

This distribution law is symmetric with respect to the mathematical expectation; therefore, the generalizing characteristic of the yield of rock mass in a class is its average value.

Figure 1 shows the dependence of the rock mass yield on the size class.

This dependence is parabolic:

$$
\gamma_{n}(i)=0.053+0.0611 \cdot i-0.0066 \cdot i^{2}, i=1,2, \ldots, 6 .
$$

The coefficient of determination $\mathrm{R}^{2}=0.926$, which indicates a high level of adequacy of this model.

Similar studies were carried out for the yield of copper in a single sample of each size class. First of all, the agreement with the normal distribution law was checked. The calculation results are shown in table 9.

Table 3-7 shows that, with the exception of class 1-0.5 $\mathrm{mm}$, agreement with the normal distribution law can be considered satisfactory. 


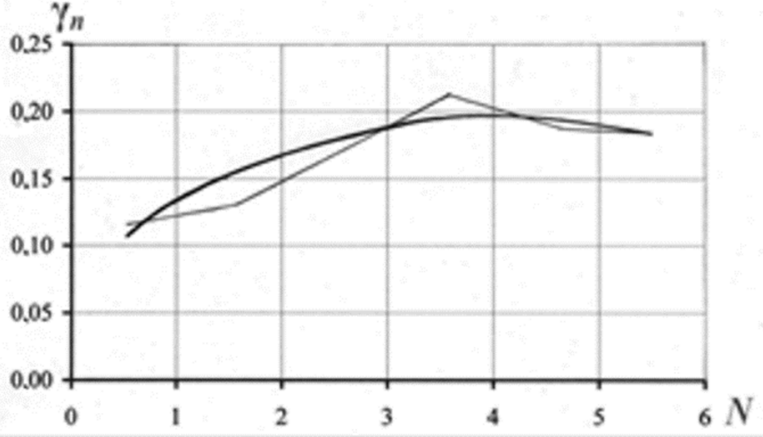

Fig. 1. The nature of the dependence of the yield of crushed rock on the size class.

Table 9. Dependence of the copper yield on the controlled size classes.

\begin{tabular}{|c|c|c|c|c|c|c|}
\hline $\begin{array}{c}\text { Class } \\
\text { number, } \\
\mathrm{N}\end{array}$ & $\begin{array}{c}\text { Size } \\
\text { limits in } \\
\text { class, } \\
\mathrm{mm}\end{array}$ & $\begin{array}{c}\text { Class } \\
\text { output }\end{array}$ & $\begin{array}{c}\text { Copper } \\
\text { output } \\
\text { in class }\end{array}$ & $\begin{array}{c}\text { Copper } \\
\text { yield } \\
\text { over the } \\
\text { entire } \\
\text { sample, } \\
\mathrm{kg}\end{array}$ & $\begin{array}{c}\text { Copper } \\
\text { output } \\
\text { based on } \\
\text { accumulated } \\
\text { results, kg }\end{array}$ & $\begin{array}{c}\text { Cumulative } \\
\text { copper } \\
\text { output, \% }\end{array}$ \\
\hline 1 & $0.1-0.05$ & 0.1075 & 0.0052 & 0.00056 & 0.00056 & 0.05 \\
\hline 2 & $0.5-0.1$ & 0.1488 & 0.0058 & 0.00086 & 0.0014 & 0.14 \\
\hline 3 & $1-0.5$ & 0.1769 & 0.00966 & 0.0017 & 0.0031 & 0.31 \\
\hline 4 & $5.0-1.0$ & 0.1918 & 0.0142 & 0.0027 & 0.0058 & 0.58 \\
\hline 5 & $10.0-5.0$ & 0.1935 & 0.0166 & 0.0032 & 0.009 & 0.91 \\
\hline 6 & +10 & 0.1820 & 0.0143 & 0.0026 & 0.012 & 0.17 \\
\hline
\end{tabular}

Dependences of rock mass yield $\gamma_{\mathrm{p}}$ and yield copper $\gamma_{m}$ on the size class are shown in Fig. 1 and Fig. 2, respectively. From both graphs it can be seen that the main copper content corresponds to classes 4 and 5 , that is, classes 5-1 and 10-5 (mm).

Table 10. Dependence of the output of copper by size class cumulative.

\begin{tabular}{|c|c|c|c|c|c|}
\hline $\begin{array}{c}\text { Class } \\
\text { number, } \mathbf{N}\end{array}$ & $\begin{array}{c}\text { Size } \\
\text { limits in } \\
\text { class, } \mathbf{m m}\end{array}$ & $\begin{array}{c}\text { Average } \\
\text { copper yield } \\
\text { per class, } \\
\mathbf{X}_{\mathbf{m}}, \mathbf{k g}\end{array}$ & $\begin{array}{c}\text { Root mean } \\
\text { square } \\
\text { deviation, } \\
S\end{array}$ & $\begin{array}{c}\text { Asym- } \\
\text { metry, } \\
A_{S}\end{array}$ & $\begin{array}{c}\text { Excess, } \\
\mathbf{E}\end{array}$ \\
\hline 1 & $0.1-0.05$ & 0.0051 & 0.00239 & -0.654 & -0.3840 \\
\hline 2 & $0.5-0.1$ & 0.0058 & 0.00266 & -0.569 & 0.0547 \\
\hline 3 & $1-0.5$ & 0.0100 & 0.00600 & 1.278 & 1.6400 \\
\hline 4 & $5.0-1.0$ & 0.0127 & 0.00630 & -0.280 & -1.3900 \\
\hline 5 & $10.0-5.0$ & 0.0177 & 0.01170 & 0.590 & -0.8760 \\
\hline 6 & +10 & 0.0140 & 0.01000 & 1.228 & 0.6300 \\
\hline
\end{tabular}

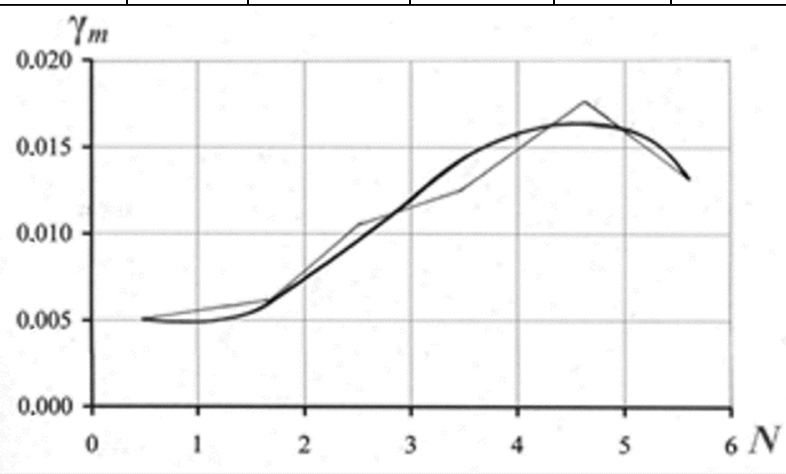

Fig. 2. Dependence of the copper yield on the size class.
It was found that the dependence of the copper yield $\gamma_{\mathrm{M}}(i)$ from class $i$ with a high level of adequacy obey the cubic parabola law:

$$
\begin{aligned}
& \gamma_{m}(i)=0.01063-0.009334 \cdot i+0.004351 \cdot i^{2}- \\
& -0.000449 \cdot i^{3}, R^{2}=0.9682 .
\end{aligned}
$$

For the sake of completeness, let us consider the indicator "copper yield in the class by the cumulative total in relation to the entire sample", which was defined as

$$
\gamma(i)=\gamma_{n}(i) \cdot \gamma_{m}(i)
$$

The calculation results for the output of copper in the size classes by the cumulative total in fractions and percentages are given in Table 10 and Fig. 3.

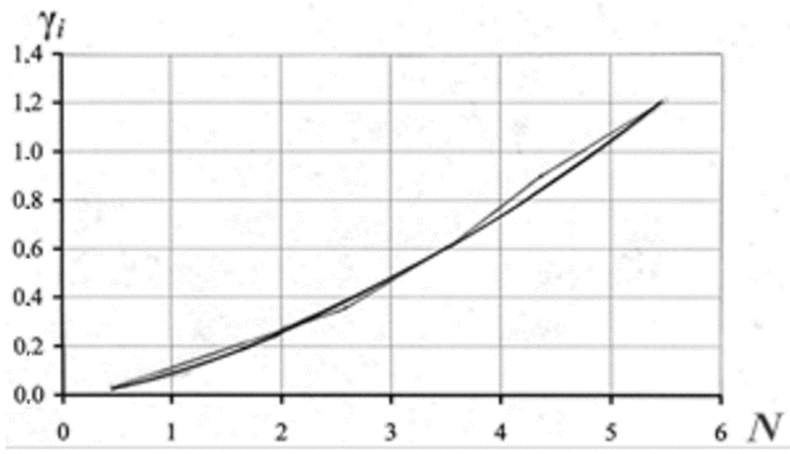

Fig. 3. Dependence of the distribution of the yield of copper by size classes by the cumulative total.

As can be seen from Fig. 3, the dependence of the cumulative copper yield on the size class with a high level of adequacy is described by a quadratic parabola:

$$
\begin{aligned}
& \gamma(i)=-0.0384+0.0479 \cdot i+0.0263 \cdot i^{2}, i=1,2, \ldots 6 \\
& R^{2}=0.994
\end{aligned}
$$

The resulting graph in Fig. 3, as well as the dependences in Fig. 1, 2, confirms the highest efficiency in terms of copper yield in classes 1-5 and 5-10 mm [38, 39].

Thus, the performed studies made it possible to establish that for lavobrekcia, the regularity of the yield of crushed mass from the size class is parabolic $\left(\mathrm{R}^{2}=0.926\right)$, and the distribution of the copper yield from the size class obeys the cubic parabola law $\left(\mathrm{R}^{2}=0.9682\right)$. The indicated high values of the coefficients of determination $R^{2}$ indicate a high degree of adequacy of these models [40].

The obtained regularities of the distribution of rock mass and copper yield by size class are relevant and can be used for predictive calculations in the development of an integrated technology for ore preparation $[41,42]$.

\section{Conclusions}

The considered features of distribution of technological indicators (output, copper content and production) on size classes allow defining the basic factors influencing 
process of crushing. The regression dependences of copper yield on the influencing factors are obtained.

Thus, the performed studies made it possible to establish that for lava breccia, the regularity of the yield of crushed mass from the size class is parabolic $\left(\mathrm{R}^{2}=\right.$ 0.926), and the distribution of the copper yield from the size class obeys the cubic parabola law $\left(\mathrm{R}^{2}=0.9682\right)$. The indicated high values of the coefficients of determination $\mathrm{R}^{2}$ indicate a high degree of adequacy of these models.

The high adequacy of the obtained models was confirmed and the most promising size classes of rocks for copper mining were identified.

The regression dependences of copper yield on the influencing factors are obtained. The obtained results and models will allow to develop a generalized model of the copper mining process and to implement this process with rational and optimal parameters. Also, the received models will allow carrying out an estimation of productivity of a research site of processing of raw materials of basalt quarries.

\section{References}

1. J. Wu, J. Yang, N.u Nakagoshi, X. Lu, H. Xu, Process Mineralogy of a Low Grade Cu-Ni-PGM Sulphide Ore and its Implications for Mineral Processing. Advanced Materials Research 524-527, 1023-1028 (2012). doi:10.4028/www.scientific.net/AMR.524527.1023

2. J. Zeng, J. Li, H. Zhu, Geologic Feature of Shilipo Copper Deposit in Xinjiang. Advanced Materials Research 881-883, 1607-1610 (2014). doi:10.4028/www.scientific.net/AMR.881-883.1607

3. S.-B. Choi, Y.-H. Kim, A New Processing Technology of Comprehensive Utilization on the Gold Copper Ore. Advanced Materials Research 1089 , 53-58 doi:10.4028/www.scientific.net/AMR.1089.53

(2015).

4. J. (C.M.) Kao, W.-P. Sung, R. Chen, Flotation of Copper Oxide Minerals Using Ethylene Phosphate as Activators. Advanced Materials Research 581-582, 975-982

(2012). doi:10.4028/www.scientific.net/AMR.581-582.975

5. J. Li, H. Hu, Development and Utilization of Circular Economy and Urban Mining - Chengdu City Based Renewable Resource Industry Survey. Applied Mechanics and Materials 768, 644-651 (2015). doi:10.4028/www.scientific.net/AMM.768.644

6. X.D. Xu, B. Li, Q.M. Lu, X.Y. Yan, J.L. Li, Flotation Test of High Sulfur Copper Ore in the Northwest in Yunnan. Applied Mechanics and Materials (556-562, 201-204 doi:10.4028/www.scientific.net/AMM.556-562.201

7. A. Baibatsha, K. Dyussembayeva, A. Bekbotayev, Material Composition of Technogenic Ores in Tails of Zhezkazgan Enrichment Factory (Central Kazakhstan). Applied Mechanics and Materials 858, 366-370 doi:10.4028/www.scientific.net/AMM.858.366
8. G. Chang, J.-Sh. Young, W. Wisnoe, Novel Method of Developing Nanosilica Coated Alumina Micro Abrasives Using Silicon Nanoparticles Generated from Spark Erosion as the Source. Applied Mechanics and Materials 799-800, 479-482 (2015). doi:10.4028/www.scientific.net/AMM.799-800.479

9. O.V. Samoilova, E. A. Trofimov, E.R. Vakhitova, Effect of Cerium and Lanthanum Additives on the Phase Composition of the Copper-Nickel Alloys. Materials Science Forum 946, 123-128 (2019). doi:10.4028/www.scientific.net/MSF.946.123

10. Y. Q. Meng, Sh. J. Dai, Zh. G. Hu, L. N. Tian, The Experiment Study on a Copper-Molybdenum Ores in Mongolia. Advanced Materials Research 454, 342347

(2012).

doi:10.4028/www.scientific.net/AMR.454.342

11. Y. V. Chui, On conjugation conditions in the filtration problems upon existence of semipermeable inclusions. JP Journal of Heat and Mass Transfer 15(3), 609-619 (2018). doi:10.17654/hm015030609.9

12. K. Rysbekov, D. Huayang, T. Kalybekov, M. Sandybekov, K. Idrissov, Y. Zhakypbek, G. Bakhmagambetova, Application features of the surface laser scanning technology when solving the main tasks of surveying support for reclamation. Mining of Mineral Deposits 13(3), 40-48 (2019). doi: 10.33271/mining13.03.040

13. I. D. Van der Werf, D. Fico, G. E. De Benedetto, L. Sabbatini, The molecular composition of Sicilian amber. Microchemical Journal 125, 85-96 (2016). http://doi.org/10.1016/j.microc.2015.11.012

14. V.I. Alekseev, The beetles (Insecta: Coleoptera) of Baltic amber: the checklist of described species and preliminary analysis of biodiversity. Zoology and Ecology 23(1), 5-12 doi:10.1080/21658005.2013.769717

15. B.R. Rakishev, A.A. Orynbay, A.M. Auezova, A.E. Kuttybaev, Grain size composition of broken rocks under different conditions of blasting. Mining Informational and Analytical Bulletin (8), 83-94 (2019). doi:10.25018/0236-1493-2019-08-0-83-94

16. O. Kovrov, K. Babiy, B. Rakishev, A. Kuttybayev, Influence of watering filled-up rock massif on geomechanical stability of the cyclic and progressive technology line. Mining of Mineral Deposits 10(2), 55-63 (2016). doi:10.15407/mining10.02.055

17. M. Adamaev, A. Kuttybaev, A. Auezova, Dynamics of dry grinding in two-compartment separator mills, in New Developments in Mining Engineering 2015: Theoretical and Practical Solutions of Mineral Resources Mining (CRC Press, 2015), pp. 435-439. doi:10.1201/b19901-76

18. A. Kopesbayeva, A. Auezova, M. Adambaev, A. Kuttybayev, Research and development of software and hardware modules for testing technologies of rock mass blasting preparation, in New Developments in Mining Engineering 2015: Theoretical and Practical Solutions of Mineral Resources Mining 
(CRC Press, 2015), pp. 185-192. doi:10.1201/b19901-34

19. B.R. Rakishev, A.M. Auezova, A.Ye. Kuttybayev, A.U. Kozhantov, Specifications of the rock massifs by the block sizes. Naukovyi Visnyk Natsionalnoho Hirnychoho Universytetu. 6, 22-27 (2014)

20. D. Antoljak, D. Kuhinek, T. Korman, T. Kujundzic, Dependency of specific energy of rock cutting on specific drilling energy. Rudarsko Geolosko Naftni Zbornik 33(3), 23-32 (2018). doi:10.17794/rgn.2018.3.3

21. O. Belichenko, J. Ladzhun, Complex gemological research of new types of treated amber. Visnyk of Taras Shevchenko National University of Kyiv. Geology 4(75), 30-34 (2016). doi:10.17721/17282713.75.04

22. A. Krek, M. Ulyanova, S. Koschavets, Influence of land-based Kaliningrad (Primorsky) amber mining on coastal zone. Marine Pollution Bulletin (131), 1-9 (2018). doi:10.1016/j.marpolbul.2018.03.042

23. J. Poulin, K. Helwig, The characterization of amber from deposit sites in western and northern Canada. Journal of Archaeological Science: Reports (7), 155168 (2016). doi:10.1016/j.jasrep.2016.03.037

24. A. Kostina, V. Zvereva, A. Pyatakov, Influence of Sulfur Content in Tailings on Processes of Hypergene and Technogene Mineral Formation on the Example of Kavalerovo Tin-Ore District. Advanced Materials Research 1051, 605-609 (2014)

25. A. Kozhonov, Zh. Maymanova, A. V. Kritskii, Choice of Efficient Technology for Aged Enrichment Tailings Processing. Materials Science Forum 946, 558-563 (2019)

26. Abhilash, B.D. Pandey, T.R. Mankhand, Copper Refining Electrolyte and Slime Processing Emerging Techniques. Advanced Materials Research 828, 93-115 (2013)

27. Z. Liu, X. Dong, Zh. Liu, Q. Liu, The Study on Copper-Molybdenum Polymetallic Mine OreControlling Structure Conditions and Mineralization Forecast of the Jiudingshan. Advanced Materials Research 807-809, 2205-2208 (2013). doi:10.4028/www.scientific.net/AMR.807-809.2205

28. V. J. Zepeda, D. Cautivo, P. A. Galleguillos, J. Soto, Y. Contador, C. Demergasso, Bioleaching of Covellite from Low Grade Copper Sulphide Ore and Tails. Advanced Materials Research. 825, 262-265 (2013)

29. Q. Y. Xing et al., Study on the Gemological Characteristics of Amber from Myanmar and Chinese Fushun, Key Engineering Materials 544 (2013)

30. V. Poturaev, A. Voloshin, V. Ponomarev, Onedimensional flow of a two-phase medium. Soviet Applied Mechanics 25(8), 843-850 (1989)

31. K. Sai, Z. Malanchuk, M. Petlovanyi, P. Saik, V. Lozynskyi, Research of thermodynamic conditions for gas hydrates formation from methane in the coal mines. Solid State Phenomena (2019) doi:10.4028/www.scientific.net/SSP.291.155

32. A.M. Zakharenko, K.S. Golokhvast, Using Confocal Laser Scanning Microscopy to Study Fossil Inclusion in Baltic Amber, a New Approach. Key Engineering Materials $\quad \mathbf{8 0 6}$ (2019). doi:10.4028/www.scientific.net/KEM.806.192

33. V. Lozynskyi, P. Saik, M. Petlovanyi, K. Sai, Z. Malanchuk, Substantiation into mass and heat balance for underground coal gasification in faulting zones. Inzynieria Mineralna. Journal of the Polish Mineral Engineering Society 19(2) (2018)

34. S. Semerikov, S. Chukharev, S. Sakhno, A. Striuk, V. Osadchyi, V. Solovieva, T. Vakaliuk, P. Nechypurenko, O. Bondarenko, H. Danylchuk, Our sustainable coronavirus future. $\mathrm{E} 3 \mathrm{~S}$ Web of Conferences 166, $00001 \quad$ (2020). doi:10.1051/e3sconf/202016600001

35. S. Sakhno, L. Yanova, O. Pischikova, S. Chukharev, Study of the influence of properties of dusty ferromagnetic additives on the increase of cement activity. E3S Web of Conferences 166, 06002 (2020). doi:10.1051/e3sconf/202016606002

36. V. Panayotov, M. Panayotova, S. Chukharev S. Recent studies on germanium-nanomaterials for LIBs anodes. E3S Web of Conferences 166, 06012 (2020). doi:10.1051/e3sconf/202016606012

37. S. Pysmennyi, M. Fedko, N. Shvaher, S. Chukharev, Mining of rich iron ore deposits of complex structure under the conditions of rock pressure development. E3S Web of Conferences 201, 01022 (2020). doi:10.1051/e3sconf/202020101022

38. V. Nadutyi, V. Korniyenko, Z. Malanchuk, O. Cholyshkina, Analytical presentation of the separation of dense suspensions for the extraction of amber. E3S Web of Conferences 109, 00059 (2019). doi:10.1051/e3sconf/20191090005

39. Z. Malanchuk, V. Korniyenko, Ye. Malanchuk, A. Khrystyuk, M. Kozyar, Identification of the process of hydromechanical extraction of amber. E3S Web of Conferences 166, $02008 \quad$ (2020). doi:10.1051/e3sconf/202016602008

40. V. Moshynskyi, Z. Malanchuk, V. Tsymbaliuk, L. Malanchuk, R. Zhomyruk, O. Vasylchuk, Research into the process of storage and recycling technogenic phosphogypsum placers. Mining of Mineral Deposits 14(2), 95-102 (2020). doi:10.33271/mining14.02.095

41. Z.R. Malanchuk, V.S. Moshynskyi, V.Ya. Korniyenko, E.Z. Malanchuk, V.H. Lozynskyi, Substantiating parameters of zeolite-smectite puffstone washout and migration within an extraction chamber. Naukovyi Visnyk Natsionalnoho Hirnychoho Universytetu (6), 1-9 (2019)

42. Ye. Malanchuk, V. Korniienko, L. Malanchuk, V. Zaiets, Research into the moisture influence on the physical-chemical tuff-stone characteristics in basalt quarries of the Rivne-Volyn region. E3S Web of Conferences, 211, $01036 \quad$ (2020). doi:10.1051/e3sconf/202020101036 